\title{
LA REAL ADUANA DE BUENOS AIRES Y LA QUIEBRA DE SU PRIMER ADMINISTRADOR: FRANCISCO XIMÉNEZ DE MESA. DOMINACIÓN Y CONTROL REAL EN UNA SOCIEDAD DE ANTIGUO RÉGIMEN*
}

\author{
THE ROYAL CUSTOMS OF BUENOS AIRES AND THE BANKRUPTCY OF ITS \\ FIRST ADMINISTRATOR: FRANCISCO XIMÉNEZ DE MESA. DOMINATION \\ AND REAL CONTROL IN AN OLD REGIME SOCIETY
}

María Evangelina Vaccani

Becaria doctoral

Universidad Nacional de Tres de Febrero https://orcid.org/0000-0002-0745-9936

evivaccani@gmail.com

Recibido: noviembre 7 de 2018 - Aceptado: febrero 21 de 2019

\section{Resumen:}

El presente trabajo tiene como objetivo indagar sobre la capacidad de control que tenía la Monarquía en las instituciones fiscales del Virreinato del Río de la Plata. Para dar cuenta de ello se tomará la Real Aduana de Buenos Aires y se considerará el accionar de sus servidores. La Aduana se creó en 1778 con el fin de recaudar rentas sobre las mercancías puestas en circulación sobre el complejo portuario rioplatense. Se abordará la primera experiencia administrativa de Francisco Ximénez de Mesa al frente de la Aduana, quien en 1788 se declaró en quiebra y debió afrontar su procesamiento judicial. Las actuaciones del Consejo de Indias en las causas de Ximénez nos permiten conocer las acciones que desarrolló en forma conjunta con la elite local. Este estudio se propone ver cómo operaban los actores en los entramados institucionales de la Corona, a fin de repensar el sistema de dominación operante en la realidad política americana. Las fuentes consultadas son legajos del Juzgado de Crimen y de la Real Hacienda. Estas fuentes se complementarán con disposiciones, ordenanzas reales, reglamentos e instrucciones creadas para el funcionamiento normativo de la Aduana.

Palabras-clave: Aduana de Buenos Aires; servidores de la corona; sistema de dominación; Virreinato del Río de la Plata. 


\begin{abstract}
:
The present work has as objective to inquire about the capacity of control that the Monarchy had in the fiscal institutions of the Viceroyalty of the River of the Silver. To give an account of this, the Customs Real of Buenos Aires will be taken and the actions of its servers will be considered. Customs was created in 1778 in order to collect rents on the goods put into circulation on the River Plate port complex. The first administrative experience of Francisco Ximénez de Mesa will be addressed in front of the Customs, who in 1788 declared bankruptcy and had to face judicial prosecution. The actions of the Council of the Indies in the cases of Ximénez allow us to know the actions that it developed jointly with the local elite. This study proposes to see how the actors operated in the institutional frameworks of the Crown, in order to rethink the system of operative domination in the American political reality. The sources to consult are files of the Criminal Court and the Royal Treasury. These sources will be complemented with provisions, real ordinances, regulations and instructions created for the normative functioning of the Customs.
\end{abstract}

Key words: Customs of Buenos Aires; crown servers; system of domination; viceroyalty of the Rio de la Plata

\title{
Introducción
}

Las "Reformas Borbónicas" emprendidas en América a fines del siglo XVIII calaron profundamente en el Virreinato del Río de la Plata. ${ }^{1}$ En su aspecto fiscal las medidas desplegadas bajo la ola reformista transformaron la Real Hacienda rioplatense modificando profundamente la realidad socioeconómica de la región. Tres elementos se destacan ante esta reconfiguración administrativa. En primer lugar, la incorporación del Alto Perú al nuevo Virreinato y con ello los beneficios obtenidos de la producción minera en la región, los que han sido fundamentales para el sostenimiento de los crecientes gastos burocráticos y militares. En segundo lugar, la implementación del Reglamento de libre comercio y la consecuente reorganización legal de la actividad mercantil en los puertos de Buenos

\footnotetext{
${ }^{1}$ Las investigaciones sobre las "Reformas Borbónicas" se han orientado en dos direcciones. La primera enfatiza sobre su alcance absolutista y la segunda hace hincapié en el pacto de sujeción. Para el primer caso existe una bibliografía clásica para la Monarquía española y sus dominios en general. Clarece Haring, El Imperio Hispánico en América. Buenos Aires, Ed. Peuser, 1958 y John Lynch, La España del siglo XVIII, Barcelona, Crítica, 2005. En particular para el Virreinato del Río de la Plata: Ricardo Levene, Investigaciones acerca de la historia económica del virreinato del Plata. ${ }^{\mathrm{a}}$ ed. $1927-1928$. Segunda edición corregida y ampliada, 2 vols., Buenos Aires, El Ateneo, 1952; Emilio Ravignani, "El Virreinato del Río de la Plata (1776-1810)”, en Ricardo Levene (Dir. Gral.), Historia de la Nación Argentina (Desde los orígenes hasta la organización definitiva en 1862), Tomo IV, $1^{\text {a }}$ sección, Buenos Aires, El Ateneo, 1940, pp. 33-305 y José María Mariluz Urquijo, El virreinato del Río de la Plata en la época del Marqués de Avilés (1799-1801), 2da. Edición, Buenos Aires, Plus Ultra, 1987. El conjunto de trabajos permite conocer la estructura tributaria y centrar la atención en la diseñada para el Virreinato rioplatense así como conocer los objetivos subyacentes de Corona en su política fiscal. En tanto para la segunda dirección el trabajo de Ruggiero Romano, Coyunturas opuestas: la crisis del siglo XVII en Europa e Hispanoamérica, México, El Colegio de México/Fondo de Cultura Económica, 1993. En su estudio plantea ver América en el Antiguo Régimen como un conjunto de entidades políticas con características propias. Dentro de esta línea de investigación se ubican los trabajos de Federica Morelli, Territorio o Nación. Reforma y disolución del espacio imperial en Ecuador, 1765-1830, Madrid, Centro Político y Constitucional, 2005 y de Javier Kraselsky publicado en este mismo dossier.
} 
Aires y Montevideo. Esto trajo aparejado el emplazamiento de las Reales Aduanas. Y por último, la implementación del régimen de Intendencias que derivó en la ordenación y creación de nuevas Tesorerías Reales tributarias de la Real Hacienda virreinal.

El presente trabajo centrará la atención en el establecimiento de la Real Aduana de Buenos Aires en 1778 sobre el complejo portuario rioplatense ${ }^{2}$. Este hecho fue una novedad en el sentido de que la nueva institución centralizó en un ramo hacendario las rentas procedentes de las mercancías puestas en movimiento. Con antelación a esto, los estudios sobre el comercio ultramarino han puesto de manifiesto que desde 1622 en Buenos Aires la actividad mercantil se desarrolló bajo el sistema de los registros sueltos de navío. A los que se sumaron otros tipos de navegación mercantil legal, además de la ilegal muy estudiada. ${ }^{3}$ La recaudación de rentas aplicadas al comercio corría a cuenta de oficiales reales de la caja porteña. ${ }^{4}$ Así, con precisas instrucciones reglamentadas se puso en funcionamiento el despacho aduanero y se designó a Francisco Ximénez de Mesa como primer administrador. Nos interesa como objetivo específico analizar su desempeño a fin de indagar la capacidad de control que tenía la Corona sobre sus funcionarios en América. El caso cobra relevancia por un extenso juicio iniciado tras su quiebra en 1788 . Ximénez de Mesa es acusado de utilizar su cargo real para realizar negociados personales y defraudar los fondos del tesoro real. Junto a él fueron procesados quienes fueron reputados en tanto que cómplices y asociados.

Este análisis se propone como objetivo general indagar cómo operaban los actores locales en el entramado institucional de la Corona, a fin de repensar el sistema de dominación que imperaba en la realidad política americana. Considerando los objetivos propuestos se maneja como hipótesis de trabajo que los servidores de la Corona desarrollaban estrategias económicas puntuales, entre las que se evidencia la utilización de sus cargos en la aduana para enriquecerse, en vez de velar por los objetivos de la Monarquía.

\footnotetext{
2 Fernando Jumar, “La región Río de la Plata y su complejo portuario durante el Antiguo Régimen”, en: Raúl Fradkin (Dir.), Historia de la provincia de Buenos Aires. Tomo 2. De la conquista a la crisis de 1820, Buenos Aires, Edhasa, 2012, pp. 124-157.

3 A principios del siglo XVIII la ruta atlántica por Buenos Aires cobra relevancia por el desarrollo del comercio ilegal y legal, que se combinan con excepciones exclusivamente a título particular. Juan Carlos Garavaglia, "El Río de la Plata en sus relaciones atlánticas: una balanza comercial (1779-1784)” en Garavaglia, Juan Carlos, Economía, sociedad y regiones, Buenos Aires, Ediciones de la Flor, 1987, pp. 65-117 y Fernando Jumar, Le commerce atlantique au Río de la Plata, 1680-1778, 2da. ed. aumentada, 1 a ed. electrónica, La Plata, UNLP, 2010, http://www.memoria.fahce.unlp.edu. ar/tesis/te.364/te.364.pdf. En este punto vale resaltar que la apertura comercial se fue dando de forma progresiva en el siglo en cuestión y de forma definitiva con el reglamento comercial de 1778. Como antecedente de ello, es el bando de la libre internación vía Buenos Aires-Potosí en 1777 que dio legalidad a la integración mercantil del espacio rioplatense y el altoperuano.

4 Zacarías Moutoukias, Contrabando y control colonial en el siglo XVII, Buenos Aires, CEAL, 1988.
} 
Una vez en sus cargos estos constituían una “armazón”, a través del cual y mediante su experiencia profesional se vinculaban con otros actores con el fin de obtener reconocimiento político que se traducía en beneficios económicos. Considerando la imposibilidad de la Corona de imponer su voluntad por la fuerza a fin de cumplir con sus objetivos de mínima a la hora de implantar el absolutismo, ésta no tuvo más opción que negociar con los cuerpos sociales presentes en la sociedad americana.

Para entender la relación existente entre la Monarquía y sus dominios americanos se ha consolidado como explicación el paradigma colonial ${ }^{6}$. Sostiene que América era un conjunto de mercados cautivos y fuentes parasitarias de renta del cual la metrópoli extraía los excedentes del aparato productivo a través de instituciones políticas y administrativas. Estudios recientes han puesto en evidencia que tal explicación no es suficiente para entender la compleja relación entre la Corona y sus dominios. Para ello han centrado su visión en la sociedad americana en el Antiguo Régimen y los actores locales7.

En la actualidad se cuestiona la noción de poder absoluto de la Corona española. John Elliott describió la naturaleza política del conjunto en tanto que 'monarquía compuesta'. Su análisis observa el grado de control que ejercía el monarca sobre sus dominios, indicando que dependía de los instrumentos políticos y militares disponibles para conseguirlo. Para el caso del sistema de dominación Hispanoamericano señala que dependía del consenso logrado entre la Corona y las elites locales, quienes ofrecieron su lealtad al Rey a cambio de reconocimientos y de privilegios ${ }^{8}$. Tras el ascenso de la dinastía Borbónica al trono, su impulso reformador significó un intento de superar esta naturaleza compuesta del poder y dar un giro definitivo hacia la centralización política. ${ }^{9}$

\footnotetext{
5 José María Imízcoz Beunza, "Comunidad, red social y elites. Un análisis de la vertebración social en el Antiguo Régimen” en José María Imízcoz Beunza (Dir.), Elites, poder y red social. Las élites del País Vasco y Navarra en la Edad Moderna, Bilbao, Universidad del País Vasco, 1996, pp. 13-50. La idea de 'armazón' en el caso de la centralización corporativa permite analizar el papel activo de los individuos a la hora de formar corporaciones integradas al sistema político en el siglo XVIII, a partir de sus actividades socio-profesionales. Javier Kraselsky, "Las estrategias de los actores del Río de la Plata: las Juntas y el Consulado de comercio de Buenos Aires a fines del Antiguo Régimen (1748-1809)”, Tesis de Doctorado inédita, Universidad Nacional de La Plata, 2011.

6 Bajo este paradigma colonial Carlos Sempat Assadourian, El sistema de la economía colonial. El mercado interno. Regiones y espacio económico, México, Nueva Imagen, 1983, ha explicado la articulación política y económica del espacio peruano en los siglos XVI y XVII. En este espacio la producción de plata potosina actuaba como polo de crecimiento económico y articulador de las actividades productivas. En tanto Lima era el polo político y comercial que centralizaba los beneficios económicos del espacio a fin de remitirlos a la península.

7 Por sociedad de Antiguo Régimen se entiende, desde el sentido sociopolítico, una sociedad en la que se establecen lazos horizontales y verticales entre las diferentes jerarquías y cuerpo que la integran, y en donde cada uno de estos posee un poder relativo de acción y negociación respecto a otros cuerpos. Ver: Antonio Hespanha, Vísperas de Leviatán. Instituciones y poder político (Portugal, siglo XVII), Madrid, Taurus, 1989. J. Mª . Imízcoz Beunza, "Comunidad, red social...”.

8 John Elliott, “A Europe of Composite Monarchies” en Past and Present, 137, 1992, pp. 48-71.

${ }^{9}$ Alejandra Irigoin; Regina Grafe, "Bargaining for Absolutism. A Spanish Path to Nation State and Empire Building”, en Hispanic American Review, 88, 2, 2008, pp. 173-209.
} 
$\mathrm{Al}$ analizar este proceso desde la perspectiva fiscal, se observa que la centralización es producto del complejo proceso de negociación para lograr financiar los aparatos monárquicos y las políticas desplegadas al efecto. De modo que la estructura fiscal de la Monarquía se engendró a partir de su propia naturaleza de poder, donde prima la soberanía fragmentada, que deriva en un ejercicio difusa del poder. Ante el impulso real de afianzar el absolutismo, los súbditos americanos se aferraron a la tradición pactista y a los privilegios, fomentando la petición y la negociación, hasta acordar compromisos aceptables consensuados. Alejandra Irigoin y Regina Grafe observan que lo que caracterizó a la Corona fue que los canales de negociación estaban menos definidos y eran más numerosos ${ }^{10}$. Con lo señalado se busca explicar la naturaleza política de la monarquía española en el entramado de relaciones que se activaron junto al "reformismo" en su aspecto fiscal.

Para el caso del Río de la Plata la propuesta de centralización corporativa, diseñada por Javier Kraselsky, ejemplifica la negociación política en el estudio de las corporaciones mercantiles permitiendo profundizar el análisis del complejo sistema político. A partir de este análisis se logra determinar cómo los miembros del Consulado porteño negocian privilegios ante la Corona. La conceptualización de centralización corporativa que Kraselsky desarrolla en este dossier logra explicar la relación entre la Corona y los súbditos locales, considerando los objetivos que cada actor persigue y las prácticas empleadas para alcanzarlos, en una sociedad constituida por diversos cuerpos actuantes, sin perder de vista las peculiaridades del Antiguo Régimen.

A esta compleja realidad política, le han sumado la dimensión fiscal del poder monárquico bajo el concepto de estado fiscal militar en el siglo XVIII. En este sentido Rafael Torres Sánchez vincula al ejercicio de autoridad gubernamental en materia fiscal con la capacidad de atraer apoyos sociales en pos de obtener recursos para sostener la guerra ${ }^{11}$. La noción permite entrecruzar los objetivos políticos en materia fiscal con la capacidad que tenía la Corona para su consecución y definir el problema de la reforma hacendaria en términos económicos. A su vez revaloriza la guerra como motivo que dio legitimidad al consenso político resultante de la negociación entre la Corona y las corporaciones de la sociedad, cuestión que viabilizó la reestructuración hacendaria y la centralización de

\footnotetext{
${ }^{10}$ La evolución de la institucionalidad y de la política de la Monarquía Hispánica ha sido estudiada en comparación con la evolución de la Monarquía Inglesa, buscando explicar el triunfo del capitalismo inglés y la bancarrota de España. Ver: John Elliott, Imperios del mundo Atlántico. España y Gran Bretaña en América (1492-1830), Madrid, Taurus, 2006.

${ }^{11}$ Rafael Torres Sánchez, El precio de la Guerra. El Estado fiscal-militar de Carlos III (1779-1783), Madrid, Marcial Pons, 2013 .
} 
recursos. En función de lo expuesto, hay que considerar el papel de América en el conjunto, antes de seguir avanzando con la delimitación de los contornos de la Monarquía como un Estado fiscal-militar, para que esta visión del conjunto sea adecuada a la realidad americana. $^{12}$

En dirección de repensar la naturaleza política de las monarquías modernas y buscando superar las explicaciones dadas a la visión compuesta del poder, se ha planteado flexibilizar el modelo y para el periodo Habsburgo se propone la visión policéntrica ${ }^{13}$. Despojada del nacionalismo axiomático sobre la cual se montaron las explicaciones del estado-nación, el policéntrismo propone una mirada global a partir de la circulación y constitución política de la monarquía en la pluralidad de espacios que la constituían. La Monarquía se presenta como un conglomerado territorial caracterizado por la ausencia de un sólo centro y en el cual los poderes actuaban desde puntos distantes entre sí. Entiende que la globalidad del poder estaba dada por las relaciones de los centros y la uniformidad de los aspectos religiosos universalistas que aseguraban la cohesión política, donde los conflictos jurisdiccionales no estaban ausentes. ${ }^{14}$ Profundizar el estudio de las lógicas de poder y las formas gobierno que operaron en el siglo XVIII, habilitará a ahondar la reflexión aquí presentada ${ }^{15}$.

El provecho de este estudio radica en la necesidad de analizar la relación de la Corona a través de las instituciones fiscales y los actores que las administraban. Los servidores reales ${ }^{16}$ eran designados por la Corona con el objetivo de monopolizar los recursos

${ }^{12}$ Fernando Jumar; María Emilia Sandrín, "La estructura del gasto de la Real Hacienda en Buenos Aires, $1734-1742$. La Corona y la economía local” en Ernest Sánchez Santiró (Coord.), El Gasto Público en los imperios ibéricos, S. XVIII, México, Instituto Mora, 2015, pp. 205-272 y Nicolás Biangardi, "Financiamiento y distribución del gasto en la caja real de Maldonado (Río de la Plata) 1782-1806” en América Latina en la Historia Económica, 23, 2, 2016, pp. 7-35.

${ }^{13}$ La Red Columnaria está formada por investigadores que se proponen compartir metodologías e intereses representados en nodos temáticos. Presenta su programa de investigación en: http://www.um.es/redcolumnaria/ (consulta 08/01/2018).

${ }_{14}$ Pedro Cardim; Tamar Herzog; José Javier Ruiz Ibáñez; Gaetano Sabatini, Polycentric Monarchies. How did Early Modern Spain and Portugal achieve and maintain global hegemony, Eastbourne, Sussex Academy Press, 2012.

${ }^{15}$ En esta dirección se destaca el reciente dossier presentado por Martín Wasserman (Coord.), "Gobierno y Administración de los Erarios de la Monarquía Hispana en las Indias, siglo XVIII” en Anuario del Instituto de Historia Argentina, 18, 2, 2018.

${ }^{16}$ La utilización del concepto de servidores reales permite despojarnos de las connotaciones estatalistas que conlleva la utilización del concepto de "funcionario", que remite al tipo ideal de la racionalidad moderna burocrática weberiana. La noción de servicio habilita a contemplar el imaginario político de la época, en relación al comportamiento, a las expectativas que el cargo imponía y a la praxis que lo modelaba. Definiendo sus prácticas como habitus. Arndt Brendecke; María Ángeles Martín Romera, "El «habitus» del oficial real: ideal, percepción y ejercicio del cargo en la monarquía hispánica (siglos XV-XVIII)" en Studia Historica: Historia Moderna, 39, 1, 2017, pp. 23-51, pp. 29-30. Max Weber, Economía y sociedad. Esbozo de sociología comprensiva, Trad. de José Medina Echavarría y otros, ed. preparada por Johannes Winckelmann, notas José Medina Echavarría, $2^{\mathrm{a}}$ ed., $17^{\mathrm{a}}$ reimpresión, México, Fondo de Cultura Económica, 2008. 
desplegados, en pos de contrarrestar el poder de los cuerpos políticos arraigados. Una vez en el cargo, estos se incorporaban a la sociedad local y creaban intereses propios. La práctica era tolerada por la Corona ya que sin estos funcionarios sus intenciones no se materializaban. En esta dirección destacamos los trabajos sobre la corrupción en el siglo XVII, analizada a partir de las prácticas mercantiles de las oligarquías porteñas. Reparando en que el contrabando se consolidó como la actividad económica dominante, la cual permitió sostener el aparato burocrático y militar en la región. Estas acciones se engendraron y sostuvieron en la misma lógica mercantil vigente. ${ }^{17} \mathrm{En}$ tal sentido, observamos una continuidad en las prácticas de los servidores reales en paso del siglo XVII al XVIII. Dichas acciones se sostuvieron en el reconocimiento del poder de la Corona sostenida en una relación de dominación, la cual depende de una interdependencia entre los distintos cuerpos sociales. De este modo la concreción de la agenda política de la Corona en el proceso económico es el resultado de compromisos institucionalizados con cuerpos sociales. ${ }^{18}$

Para el caso del Río de la Plata y las provincias del Alto Perú vemos que las transformaciones institucionales se hicieron sentir a principios del siglo XVIII, ya que estas regiones fueron ganando autonomía fiscal respecto de la capital virreinal limeña. ${ }^{19}$ Con ello Buenos Aires se fue posicionando como Contaduría Mayor (1767) hasta constituirse en sede hacendaría del nuevo virreinato. En este marco se dio la instalación de la Real Aduana de Buenos Aires. Es así que nos interesa indagar cómo la Corona racionalizó la administración de sus finanzas en función de su objetivo de afirmar el absolutismo monárquico en el Virreinato del Río de la Plata, para repensar el sistema de dominación imperante, poniendo el foco de atención en la organización y administración de esta institución.

\section{Las aduanas de la Corona: ola centralizadora en América}

El siglo XVIII se caracterizó por una creciente centralización de recursos fiscales en manos de la Corona. El afán centralizador penetró de modo profundo en los dominios peninsulares de la Monarquía Hispánica. La Real Hacienda fue reestructurada con el fin de obtener mayores ingresos e información precisa de los recursos fiscales disponibles. Dos antecedentes concentran la atención de este proceso, en primer lugar la implementación

${ }_{17}$ Z. Moutoukias, Contrabando y control colonial.

${ }^{18}$ Decsi Astrid Arévalo Hernández y Oscar Rodríguez Salazar, "La fiscalidad bajo un régimen de dominación colonial: el caso de Caja Real de Cartagena, 1738-1802”, en: Anuario Colombiano de Historia Social y de la Cultura, 35, 2008, pp. 19-64, p. 22.

${ }^{19}$ Para explicar la estructuración de la Real Hacienda en Río de la Plata ver: María Evangelina Vaccani, "Antecedentes para la conformación de la estructura fiscal: el caso del Virreinato del Río de la Plata y la Real Aduana de Buenos Aires (1700-1810)" en IV Jornadas de Graduados-Jóvenes investigadores, Facultad de Humanidades y Ciencias de la Educación, Universidad Nacional de La Plata, 2012. 
de la Nueva Planta en tiempos de Felipe $\mathrm{V}^{20} \mathrm{y}$, en segundo lugar, el catastro de Ensenada pensado con el fin de homogeneizar y centralizar las rentas peninsulares. ${ }^{21}$ Más allá de los resultados de esta política centralista desplegada en la península, en la segunda mitad del siglo XVIII el contexto bélico demandaba la presencia de una Monarquía fuerte capaz de financiar los crecientes gastos, frenar la competencia comercial y preservar los dominios a cualquier precio. Rafael Torres Sánchez relaciona el papel central de la Tesorería General de la Real Hacienda con el problema de la autoridad gubernamental, en donde los Borbones pudieron poner en marcha su programa reformista y dar lugar a una institución fiscal moderna y unificada durante el reinado de Carlos III..$^{22}$ moderna y unificada durante el reinado de Carlos III. ${ }^{23}$

Este afán centralizador se extendió a los dominios americanos traducido en un extenso programa político que buscaba reafirmar el absolutismo, como en la península. Dentro de ese movimiento se incluye 1 creación de las aduanas principales de Nueva España (1749) y del Perú (1770). Como señalan Guillermina de Valle Pavón y Antonio Ibarra, las aduanas novohispanas fueron una preocupación constante de la Corona. Desde tiempos de la conquista se pusieron en funcionamiento como centros de fiscalización de productos comerciables bajo las prerrogativas exclusivas del rey. Progresivamente la recaudación de los derechos comerciales adquirió importancia. Durante los siglos XVI y XVII, la recaudación se arrendó a particulares, estuvo bajo la administración del cabildo o en manos de los oficiales ordinarios de las Cajas Reales. En Nueva España, así como para el resto de América, recién en 1778 la Corona se dispuso de hacerse del control directo de las rentas aduaneras bajo un ramo particular de la Real Hacienda. Para dar curso a su propósito se llevó a cabo una restructuración de las aduanas marítimas y terrestres que garantizaban el cobro de derechos a los bienes en circulación y la remisión de lo recaudado a la hacienda. ${ }^{24}$

Cuestión similar se suscitó en el Virreinato del Perú con la puesta en vigencia en 1778 de un nuevo Reglamento de Aduanas y administración de los Reales Derechos de Almojarifazgo y Alcabalas del Reino. El mismo establecía que las aduanas y rentas que allí

\footnotetext{
${ }^{20}$ Pedro Ruiz Torres, Reformismo e Ilustración, Historia de España, V, Barcelona, Crítica, Marcial Pons, 2008, "Fiscalidad, economía y sociedad a mediados de siglo”, pp. 253-331.

${ }^{21}$ Josep María Delgado Ribas, "Presión fiscal y asignación de recursos en la Monarquía borbónica” en Illes i Imperis, 8, 2006, pp. 25-40 y "Construir el estado, destruir la nación. Las reformas fiscales de los primeros borbones y el colapso del sistema de equilibrios en el imperio español (1714-1796)”, Illes i Imperis, 12, 2012, pp. 63-85.

${ }^{22}$ Rafael Torres Sánchez, La llave de todos los Tesoros. La Tesorería General de Carlos III, Madrid, Silex, 2012.

${ }^{23}$ Rafael Torres Sánchez, La llave de todos los Tesoros. La Tesorería General de Carlos III, Madrid, Silex, 2012.

${ }^{24}$ Antonio Ibarra; Guillermina Valle Pavón, "Las aduanas durante el virreinato en la Nueva España” en Enriquea Florescano (Coord.), Historia General de las Aduanas en México, México, Confederación de Asociaciones de Agentes Aduanales, 2004, pp. 53-110.
} 
se administraban debían quedar bajo la supervisión de la Real Hacienda. Dicho Reglamento fue una adaptación del puesto en práctica en Nueva España y Guatemala. Involucraba a todos los territorios del Virreinato exceptuando las gobernaciones de Tucumán, Paraguay, Río de la Plata y Reino de Chile que corrían con otras reglas. ${ }^{25}$

María Luisa Laviana Cuetos analiza una situación semejante para Guayaquil, ciudad portuaria desde el siglo XVI. La ciudad desempeñó un importante papel como escala en el tráfico entre Perú, Panamá y Nueva España, especialmente como puerto de entrada y salida de los artículos europeos y americanos para el territorio de la Audiencia de Quito. La autora indica que desde 1778 los productos de la Real Aduana, por primera vez, pasan a figurar en las cartas-cuenta de la Real Hacienda. Este ramo incluía los ingresos procedentes de los almojarifazgos, alcabalas, impuesto de aduana, sisa, pulperías y comisos. Rentas que existían con antelación y eran arrendadas a particulares o administradas por oficiales de cajas, que ahora quedaron bajo la administración directa de la Aduana ${ }^{26}$.

Estos antecedentes sobre la reorganización aduanera bajo la administración directa de la Real Hacienda, en las áreas centrales como Perú y Nueva España, así como áreas secundarias como Guayaquil, permiten comprobar que la creación de las aduanas en Río de la Plata no fueron disposiciones aisladas, ni azarosas. Obedece al interés de la Corona por centralizar las rentas aduaneras bajo un ramo hacendario y dar un orden reglamentado y fiscal al desarrollo comercial de la región. Ello pone de manifiesto que las acciones económicas que se condensaron a partir de 1776 son el resultado de un proceso institucional, fiscal y comercial que operó de forma paulatina.

A continuación detallaremos la creación de las aduanas del Virreinato del Río de la Plata, para luego centrarnos en los actores que administraban el despacho porteño.

\section{La Aduana en cuestión: antecedentes y reglamentación}

La conformación de la estructura administrativa virreinal para el caso del Río de la Plata se ha estudiado como algo impuesto desde arriba y presentado como resultado de intereses particulares de la Corona o de las necesidades que imponen las circunstancias históricas. ${ }^{27}$ Por el contrario vemos que los orígenes de la Real Aduana del Virreinato se remontan al año 1774, cuando el Gobernador de la ciudad porteña recibe

${ }^{25}$ Reglamento para el Gobierno de la Aduana de esta ciudad, y método de la recaudación, y administración de los reales derechos de almoxarifazgo, y alcabala del reyno del Perú..., Lima, En la oficina de la Calle de San Jacinto, 1773.

${ }^{26}$ María Luisa Laviana Cuetos, "Comercio y fisco: los «productos de la Aduana» de Guayaquil (1757-1804)" en Europa e Iberoamérica, cinco siglos de intercambios, V. II, Sevilla, Junta de Andalucía, 1992, pp. 599-615.

${ }^{27}$ Ricardo Levene, Investigaciones acerca de, p. 464. 
la orden de fundar dicha institución. La misma no fue bienvenida por los habitantes de la ciudad, ya que fue rechazada mediante el recurso al derecho de súplica, resumido en el "acato pero no cumplo". ${ }^{28}$

Sin incursionar en los alegatos de los cabildantes, es interesante señalar que este ejemplo permite visibilizar la presencia de intereses locales que atentaban contra los objetivos de la Corona. Asimismo, vemos que los actores locales tenían aceitados los mecanismos por los cuales podían oponerse a las órdenes que no se correspondían con sus propósitos. En plena ola reformista los súbditos porteños no ven necesario la instalación de la aduana y en tal sentido "percibían que estaban dejando de ser vasallos de un Reino para convertirse en habitantes de una colonia" y muestran "una resistencia a ese cambio de estatus jurídico" ${ }^{29}$. De este modo, los intereses políticos y económicos de los actores locales ponen un freno al absolutismo real.

A pesar de ello, una vez creado el Virreinato del Río de la Plata en 1776, se procedió a dotarlo de una estructura administrativa fiscal capaz de sostener los crecientes gastos en magistrados y en la defensa. La creación de la Real Hacienda fue imperiosa en pos de centralizar los recursos fiscales del Virreinato. En relación con ello, los borbones tempranamente manifestaron su interés por administrar de manera más eficientes las gobernaciones del sur del Virreinato del Perú. Para alcanzar tales objetivos en el espacio a analizar, se fueron creando instituciones fiscales autónomas capaces, en un principio, de dar autosuficiencia a los gastos militares y administrativos de la región, para luego transferir lo disponible al Erario Real. Fue así que, en 1767 se instauró la Contaduría Mayor de Buenos Aires, que quitaba de la dependencia limeña los asuntos contables y fiscales de la región, anticipando el lugar de poder que más tarde se concedió plenamente a Buenos Aires. Con la creación del Virreinato se procedió a complejizar la presencia de la Real Hacienda en Río de la Plata y forma parte de ello la creación de la Real Aduana de Buenos Aires (1778) y la Real Aduana de Montevideo (1779), con la consecuente creación del ramo de aduana. La creación del Tribunal Mayor de Cuentas (1780), dio forma a la estructura fiscal del virreinato, que absorbió y complejizó los trabajos de la Contaduría, equiparándola en cuanto a funciones y atribuciones con las ya existentes en Nueva España y Perú. De este modo quedó configurado un espacio económico fiscal autónomo, que incorporó

\footnotetext{
${ }^{28}$ Fernando, Jumar, "El precio de la fidelidad. La Guerra de Sucesión en el Río de la Plata, los intereses locales y el campo Borbón” en Annie Molinié; Alexandra Merle (Dirs.). L’Espagne et ses guerres. De la fin de la Reconquête aux guerres de l'Indépendance, París, Presses de l’Université Paris - Sorbonne, 2004, pp. 203-236.

${ }^{29}$ Fernando, Jumar, "El precio de la fidelidad”, p. 207.
} 
al Alto Perú a su jurisdicción, reservándose así los beneficios de la minería potosina. Con la implementación del sistema de Intendencias en 1782 las funciones de hacienda se centralizaron en la figura del Superintendente, cuestión que complejizaba la realidad institucional. ${ }^{30}$

En este complejo entramado administrativo fiscal focalizamos el estudio en la Aduana porteña. Partiendo de estos antecedentes, tras la creación del Virreinato y una vez reglamentada su inserción comercial a partir de la reglamentación del libre comercio, se dio curso a la instauración de la Aduana con el fin de recaudar las rentas aplicadas a los bienes circulantes por el complejo portuario. De este modo, la Real Aduana de Buenos Aires se creó por Real Orden el 25 de junio de 1778. La institución se emplazó en una vieja ranchería que contaba con las instalaciones de galpones y almacenes necesarios para el control de las mercancías circulantes, sobre las cuales los oficiales fiscalizaban sus volúmenes y tipología a fin de establecer su aforo y percibir derechos. ${ }^{31}$ En el año 1779 la Aduana de Buenos Aires comenzó a funcionar y para ello se dictó su Reglamento, con instrucciones precisas que atendían la administración de las rentas. ${ }^{32}$ Se imponían controles, que se asentaron por escrito, a los bienes que circulaban por el complejo portuario rioplatense. Las necesidades comerciales de la región dieron lugar a la creación de la Aduana en la ciudad de Montevideo el 10 de febrero de 1779.33

El Reglamento en cuestión contiene siete capítulos en los que se explicitan las instrucciones que recibieron los administradores para desempeñar una correcta ejecución de las atribuciones con que se quiso dotar la institución. El capítulo 1 regula los buques de guerra, el capítulo 2 atiende los buques de correo, el capítulo 3 detalla las instrucciones de actuación frente a la carga y descarga de mercancías, el capítulo 4 explicita el cobro de alcabalas aplicadas a los bienes entrantes y salientes de los puertos y demás jurisdicciones del virreinato, el capítulo 5 define los aranceles para géneros procedentes de los

${ }^{30}$ John Lynch, Administración colonial española 1782-1810. El sistema de Intendencias en el Virreinato del Río de la Plata, Buenos Aires, EUDEBA, 1962.

${ }^{31}$ Emilio Ravignani, "El virreinato del Río de la Plata".

${ }^{22}$ César A. García Belsunce, "La Aduana de Buenos Aires en las postrimerías del régimen colonial” en Investigaciones y Ensayos, 19, 1975, pp. 463-486.

${ }_{33}$ El puerto de Montevideo quedó sometido en primer momento a la administración porteña. Pero una vez instalada la aduana se "Resolvió el problema una orden real que, ajustada estrictamente al texto del Reglamento de 12 de octubre de 1778, dispuso que los efectos pagarían en Montevideo el almojarifazgo y lo volverían a pagar por su entrada a Buenos Aires si fueran para comerciar en ella; en tanto que el de alcabala se pagaría únicamente su entrada por Montevideo, aun para aquellas mercaderías que serían vendidas en Buenos Aires. En caso de que los efectos hubieran sido vendidos en Montevideo y luego transportados a Buenos Aires debían pagar alcabala de reventa. Los gravámenes aplicados a las mercaderías eran: por almojarifazgo, el $3 \%$ para las de origen nacional y el $7 \%$ para las de origen extranjero; la alcabala, tanto la de venta como la de reventa, era del cuatro por ciento". Aurora Capillas de Castellanos, Montevideo en el siglo XVIII, Montevideo, Nueva Tierra, 1971, pp. 47-52. 
territorios de la Monarquía y del extranjero, el capítulo 6 detalla las reglas de cuenta y razón para las distintas secciones de la administración aduanera, es decir la contaduría y tesorería, y el capítulo 7 detalla los resguardos de mar y tierra (que fueron objeto de un reglamento particular instrumentado en 1794). ${ }^{34}$

Un análisis del reglamento aduanero al calor de la realidad económica de la región permitió determinar que la aduana operó sobre una realidad comercial y mercantil que ya se desarrollaba sobre el complejo portuario rioplatense. ${ }^{35}$ Los motivos que llevaron a la creación de este ente se vinculan con los esfuerzos por mejorar la recaudación fiscal en la actividad mercantil.

La importancia económica de la aduana tanto para el periodo virreinal como para el periodo independiente es tema recurrente en la historiografía. ${ }^{36} \mathrm{~A}$ pesar de ello, su abordaje ha sido parcial o secundario. El único trabajo que aborda a la Aduana desde la óptica fiscal es un artículo de César A. García Belsunce. En él presenta un análisis de la evolución de los movimientos fiscales para el período de 1805 a 1810 y se describe el sistema de registro de los bienes transados. Además, se presenta el tratamiento desglosado del cargo y la data aduanera, discriminando los asientos de entradas y salidas en los Libros Mayores. Como ya se mencionó, la Real Aduana recaudaba ramos de Real Hacienda y además de estos, ramos particulares y ajenos. ${ }^{37}$ Para el periodo trabajado, entre los ramos de hacienda figuran los de Almojarifazgo de entrada y salida, el Derecho de Negros, Comercio de Ensayo, Derechos de Frutos, Alcabalas varias, Alcance de Cuentas, Donativos, Medias Anatas, Productos de Guías y Eslingaje de mercancías ${ }^{38}$. Los ramos particulares recaudados por esta administración eran el de Monte Pío de ministros, el Ramo Municipal de Guerra en beneficio del Cabildo y el Derecho de Sisa ${ }^{39}$. Finalmente,

\footnotetext{
${ }^{34}$ Archivo General de la Nación, Argentina (en adelante AGN), IX-14-08-03, Reglamento de Aduanas, 1779.

35 María Evangelina Vaccani, "Habilitan puerto, se lanza el libre comercio. La creación de las reales Aduanas en el Virreinato del Río de la Plata: antecedentes y realidad mercantil. (1774-1794)” en 5tas Jornadas Interdisciplinarias de Estudios Portuarios, Red Interdisciplinaria de Estudios Portuarios, 2013.

${ }^{36}$ Fernando Enrique Barba, "Algo más sobre el fracaso los derechos diferenciales" en Investigaciones y Ensayos, 55, 2005, pp. 41-49 y Tulio Halperín Donghi, Guerra y finanzas en los orígenes del estado argentino (1791-1850), 1a ed. 1982, Buenos Aires: Prometeo Libros, 2005.

${ }^{37}$ Samuel Amaral presenta un detallado inventario de los ramos hacendarios que pertenecían a la masa común donde se incluye el de aduana, los ramos particulares propios de la Corona y los ramos ajenos con destinos específicos. Explicando el origen de cada uno y los destinos de estos a partir del estudio de la Caja Real de Buenos Aires. Ver: Samuel Amaral, "La Financiación del gasto público en la Hacienda Colonial. Un análisis de las cuentas de la Caja Real de Buenos Aires, 1789-1791", en Anales de la Asociación Argentina de Economía Política, La Plata, Asociación Argentina de Economía Política, 1982, sin paginación.

${ }^{38}$ Herbert Klein, "Las finanzas del Virreinato del Río de la Plata en 1790" en Desarrollo Económico, 13, 50, 1973, pp. 369-400.

${ }^{39}$ Entre los ramos particulares figura la Sisa como el impuesto municipal recaudado para afrontar gastos locales y el Monte pio militar: impuesto aplicado al salario militar destinado a cubrir pensiones a las viudas. Herbert Klein, "Las finanzas del Virreinato", pp. 398-399.
} 
los ramos ajenos eran los de depósitos particulares y decomisos, bienes de contrabando, tercias partes, contribución a hospitales, almirantazgo, contribución patriótica, impuesto a Córdoba y de otras tesorerías. ${ }^{40}$ La institución registra un crecimiento progresivo en sus tareas fiscales y administrativas que debe ser explicado y contextualizado a lo largo del periodo virreinal.

\section{Los servidores reales y actores en el Río de la Plata}

Para el caso del Río de la Plata el estudio de los "funcionarios" se ligó al tópico de la corrupción. ${ }^{41}$ Por ejemplo, Zacarías Moutoukias a partir del análisis de las características del comercio atlántico durante el siglo XVII, las prácticas comerciales de la elite y de los "funcionarios", argumenta que la corrupción operaba como una transgresión a las disposiciones legales impuestas por la Corona. Para Moutoukias el contrabando era la actividad principal de la elite dominante que incluía a los "funcionarios". Para este autor, el comercio ilegal permitió financiar al aparato administrativo y militar de la Corona, por eso fue tolerado, ya que surgió de las condiciones creadas por el sistema comercial. ${ }^{42}$ Macarena Perusset, desde una mirada antropológica, indaga sobre el origen del contrabando observando que el fenómeno se vinculaba a las prácticas ilegales que transgreden las normas, lo que no implicaba que haya corrupción, en un sentido político legal estatal ${ }^{43}$. Por lo tanto, el contrabando, en el Antiguo Régimen, más que una práctica corrupta aparece como una respuesta a una norma jurídica impuesta. El ejercicio de un oficio en la administración resultaba de vital importancia en la medida en que permitía a los líderes de la elite comercial acceder a los mecanismos de control e influencia judicial. Para la autora esta situación continúo hasta que se decretó el libre comercio en 1778.

\footnotetext{
${ }^{40}$ C. A. García Belsunce, "La Aduana de Buenos Aires", pp. 477.

${ }^{41}$ Sucintamente señalamos que la corrupción se analizó en relación al desempeño de los funcionarios en el marco legal que ordena su desempeño. En relación a ello Horst Pietschmann, "Burocracia y corrupción en Hispanoamérica colonial. Una aproximación tentativa" en Nova América, 5, 1985, pp. 11-37, analiza la temática con el fin de rastrear a los orígenes de la corrupción en el Estado moderno. La visión weberiana de tipo racional y legal es la que caracteriza este tipo de análisis. Situando el fenómeno en la sociedad de Antiguo Régimen, y salvando el anacronismo histórico, Michel Bertrand observa la corrupción en los espacios de poder administrativos que se constituyen en jurisdicciones. Estas son analizadas a partir de atribuciones fiscales de los servidores que se sostenían en las instituciones de Antiguo Régimen. Proponiendo una clave de análisis que contemple la interacción del mundo administrativo y económico-social, señalando que la corrupción expresa la intensidad del intercambio entre los espacios sociales y de poder público y privado. Renovando de este modo la mirada del fenómeno. Michel Beltrand, "Nuevas preguntas, nuevos enfoques. La corrupción en la administración colonial española” en Francisco Andújar Castillo; María del Mar Felices de la Fuente (Coords.), Las ventas de cargos y honores en el Antiguo Régimen, Madrid, Biblioteca Nueva, 2011, pp. 46-62.

${ }^{42}$ Zacarías Moutoukias, "Burocracia, contrabando y autotransformación de las elites en el siglo XVII" en Anuario IEHS, 3,1998, pp. 213-248.

${ }_{43}$ Macarena Perusset, “Conductas y procedimientos fuera de la ley: comercio ilícito, líderes y prácticas”, Universitas humanística, 63, 2007, pp. 203-239.
} 
En confluencia con estas interpretaciones, Darío Barriera al analizar la justicia y el equipamiento político de la monarquía en el sur de la Audiencia de Charcas, en los siglos XVI y XVII, pone el acento en el aspecto jurisdiccional ${ }^{44}$. Lo que le permite sostener que la normativa emanada del poder Real creaba amplios márgenes de acción a los agentes locales, propiciando el fortalecimiento de la monarquía agregativa, compuesta y policéntrica. De este modo, se habría institucionalizado un poder político capaz de hacer fluir al centro los flujos rentísticos y de poder, a partir de normativas e instituciones que posibilitaron la construcción de poderes relacionales y jurisdiccionales ${ }^{45}$.

Jorge Daniel Gelman en su análisis sobre la lucha del control del "Estado” en tiempo de reformas, sostiene que estas crearon las condiciones para transformar las estructuras de poder ${ }^{46}$. El fin de la venta de cargos, fenómeno que originó la corrupción generalizada para el autor, dio lugar a que la elite redefiniera sus formas de acceso a la administración, y es por ello que buscaron incorporar a los nuevos servidores a su mundo. El autor sostiene que la incorporación de nuevos hombres dio éxito a las reformas en tanto buscaron reforzar el poder del Estado, la rigidez de las medidas llevó a desconocer los consensos y esto generó en el largo plazo la reaparición de las viejas prácticas. Eduardo Saguier analiza los vínculos de la corrupción y la burocracia como causa de la disgregación del poder, fenómeno que explicaría el federalismo de los tiempos independientes. Saguier también ve en el fenómeno de corrupción que los "funcionarios" abusan de la confianza puesta en ellos, lo que, junto con la crisis fiscal de comienzos del siglo XIX, socavó el poder jurisdiccional acelerando los procesos de independencia. ${ }^{46}$

Si bien, como se acaba de reseñar, se han realizado aportes para la interpretación historiográfica de la corrupción en el Río de la Plata, no se han desarrollado estudios que analicen de forma sistemática el accionar de los servidores reales en tiempos del Virreinato, desde su creación 1776 hasta su desintegración. Aparecen contribuciones fragmentarias en torno a instituciones administrativas fiscales. Sus aportes permiten comprender que previo a la instauración del Virreinato el desorden administrativo era la característica distintiva.

La dotación de un andamiaje institucional fiscal al Virreinato implicó crear

\footnotetext{
${ }_{44}$ Barriera, Darío, “Un rostro local de la Monarquía Hispánica: justicia y equipamiento político del territorio al sureste de Charcas, Siglos XVI-XVII” en Colonial Latín American Historical Review, 15, 4, 2006, pp. 377-418.

45 José Andrés Gallego, "Los Reinos de Indias, de tierra de conquista a sumisión pactada” en Conrad Russell; José Andrés Gallego (Dirs.), Las monarquías del Antiguo Régimen, ¿̇monarquías compuestas?, Madrid, Editorial Complutense, 1996, pp. 149-164.

${ }^{46}$ Jorge Gelman, "La lucha por el control del Estado: administración y elites en Hispanoamérica”, en Enrique Tándeter (Dir.); Jorge Hidalgo Lehuedé (Co-dir.), Historia General de América Latina. Tomo IV. Procesos americanos hacia la redefinición colonial, España, s/d, Ediciones de la UNESCO/Editorial Trotta, 2000, pp. 251-264.
} 
nuevas instituciones con funcionarios especializados en asuntos fiscales. Uno de los primeros en abordar tal temática fue John Lynch quien, en su libro sobre las Intendencias del Virreinato, observa que la falta de hombres fieles a las intenciones de la Corona hizo que se replicaran prácticas abusivas. Se esperaba de los servidores que no corrompieran sus funciones y estuvieran capacitados para administrar recursos ${ }^{47}$. En contraposición, se observa que las vacantes fueron ocupadas por hombres inexpertos que continuaron realizando abusos en sus servicios. El libro de Susan Socolow en el que analiza diferentes aspectos de la burocracia de Buenos Aires entre 1769-1810, presenta el tema de la corrupción a partir de un ideal de funcionario que incumplía sus deberes, infligiendo las normas y actuando en perjuicio de los intereses de la Corona ${ }^{48}$. Otro trabajo que da cuenta de la inoperancia de los funcionarios del Tribunal Mayor de Cuentas es el de José María Mariluz Urquijo. De este trabajo se desprende el fraude cometido por Francisco Ximénez de Mesa en los manejos de los fondos aduaneros. Al respecto, el autor argumenta que se podría haber evitado si el Tribunal de Cuentas hubiera actuado conforme a las reglas ${ }^{49}$.

En este sucinto estado de la cuestión entorno a los magistrados en el espacio rioplatense reparamos que lejos de provocar una revolución administrativa, como David Brading catalogó a los efectos de las reformas, reconocemos que estas intentaron algunos cambios importantes en la estructura de poder en América ${ }^{50}$. Sin embargo, no lograron alterar y transformar los fundamentos sobre los cuales operó la dominación política. Lo señalado nos aproxima a lo indicado por Jorge Gelman quien sostiene que las reformas encontraron menos resistencia en aquellos espacios en los que las elites americanas sacaron más provecho. De modo que en la segunda mitad del siglo XVIII la negociación entre la Corona, los cuerpos administrativos y las elites siguió operando bajo la lógica de los Habsburgo. La forma en que los servidores de la Corona ejercían el poder derivado de su papel en tanto que jueces, definida por la historiografía como corrupción, continuó operando para garantizar los equilibrios de poder en el contexto de las transformaciones políticas que se sucedieron en el Río de la Plata.

\footnotetext{
47 John Lynch, “Administración colonial española”.

${ }^{48}$ Susan Socolow, The Bureaucrats of Buenos Aires, 1769-1810: Amor al Real Servicio, Durham, Duke University Press, 1987.

49 José María Mariluz Urquijo, “El Tribunal Mayor y Audiencia Real de Cuentas de Buenos Aires” en Revista española de control externo, 2, 4, 1951, pp. 129-158.

${ }^{\circ}$ David Brading, "La España de los borbones y su imperio americano" en Leslie Bethell (Ed.), Historia de América Latina, Tomo 2, Barcelona, Crítica, 1990, pp. 85-125.
} 


\section{El personal de la Real Aduana de Buenos Aires}

Este apartado va a ocuparse de los servidores responsables de la Aduana. El nuevo despacho demandaba hombres especializados en el manejo de su administración y leales a las intenciones de la Corona. La centralización de las rentas aduaneras en la región fue el motor de las acciones desplegadas. El escalafón administrativo se conformaba por un Administrador, un Contador, Oficiales de Contaduría, un Tesorero, escribientes, un Receptor de Alcabalas, dos Vistas de Aduana y un Cajero oficial. La mayoría de los puestos mencionados fueron designados por orden expresa del rey y los beneficiarios no se encontraban en Buenos Aires al momento de su designación.

Gracias a la petición de aumento de sueldo y eximición del pago de media anata del año 1785 se conoce en detalle la planta que asumió la tarea de poner en marcha la Aduana de Buenos Aires. Los cargos creados fueron ocupados: por Francisco Ximénez de Mesa (Administrador), Nicolás Torrado (Contador), Juan Francisco de Villanova (Vista de Contaduría), Joseph de Villanova (Primer Oficial de Contaduría) y Francisco Esteban Gavarri (Segundo Oficial de Contaduría). ${ }^{51}$ Todos nacidos en la península y nombrados por orden expresa del Rey Carlos III y su Ministro de Indias José de Gálvez. ${ }^{52}$

La nómina de personal se amplió y nuevos cargos se sumaron a la administración y contaduría. Se crearon puestos subalternos entre 1780 y 1785 , como se muestra en el cuadro 1: Tesorero, Oficiales de Tesorería, escribientes, cajero, Administrador del Ramo de Sisa y Receptor de Alcabalas y sus respectivos oficiales. Los sueldos percibidos por estos servidores corrían por cuenta de la Real Hacienda y su variación es amplia según el rango del cargo desempeñado. Todos los cargos de primera creación reciben un aumento en el año 1785 según consta en el inventario de funcionarios de la Real Hacienda actuado en 1787 , detallándose las altas y bajas.

Volviendo sobre las intenciones de la Corona, para el caso de Nueva España, se ha trabajado la finalidad de colocar en los puestos administrativos a hombres leales a sus propósitos. En vista de centralizar la recaudación los "hombres nuevos" designados debían ser idóneos en sus funciones. A pesar de las claras intenciones políticas, las viejas

\footnotetext{
${ }^{51}$ Archivo Histórico Nacional, España (en adelante AHN), Contratación 5524, N.1, R.85, Madrid 14 de julio de 1778. Portal Pares. Considerando la nómina de personal que figura en la copia adjunta al reglamento de Aduana del año 1779, los funcionarios mencionados son los mismos que en el anterior, salvo en el caso de contador Nicolás Torrado quien fue reemplazado por Juan Joseph Núñez y ocupó el cargo desde 10 de septiembre de 1782 hasta el 25 de mayo de 1784. ${ }^{52}$ En el caso de Ximénez de Mesa, reconocemos una trayectoria como funcionario en América, previo a ocupar el cargo de administrador se desempeñó como Alcalde en Nueva España Tabasco y ocupó un cargo contable en la caja alto peruana a cargo de Francisco Paula de Sanz.
} 
María Evangelina Vaccani

usanzas se replicaron y los servidores una vez en su cargo reprodujeron intereses particulares en alianza con los actores locales. ${ }^{53}$

Cuadro 1. Servidores reales en la Aduana de Buenos Aires, 1778-1787

\begin{tabular}{|c|c|c|c|}
\hline Apellido y nombre & Cargo & Sueldo & $\begin{array}{c}\text { Fecha de } \\
\text { designación }\end{array}$ \\
\hline $\begin{array}{l}\text { Francisco Ximenéz de } \\
\text { Mesa }\end{array}$ & Administrador & 2.500 & 26-06-1778 \\
\hline Juan Josef Nuñez & Contador & 1.500 & 7/09/1782 \\
\hline Nicolás Torrado & Contador & 1.800 & $\begin{array}{l}\text { 26-06-1778 al } \\
\text { 24-04-1784 (falleció). }\end{array}$ \\
\hline José Dionicio Vilanova & Vista oficial & 1.500 & 1-06-1779 \\
\hline $\begin{array}{l}\text { Manuel Vicente de la } \\
\text { Colina }\end{array}$ & Alcalde & 800 & $1-04-1779 / 7-08-1780$ \\
\hline Martin Sánchez Cavello & Alcalde & 1.000 & 22-04-1779 \\
\hline Josef de Vilanova & $\begin{array}{l}\text { Primer oficial de conta- } \\
\text { duría }\end{array}$ & 700 & 1-06-1779 \\
\hline $\begin{array}{l}\text { Francisco Estavan Ga- } \\
\text { varri }\end{array}$ & $\begin{array}{l}\text { Segundo oficial de con- } \\
\text { taduría }\end{array}$ & 450 & 11-06-1779 \\
\hline Miguel Obbes & $\begin{array}{l}\text { Segundo oficial Conta- } \\
\text { duría }\end{array}$ & 450 & 01-01-1785 \\
\hline Eustacio Outon & Oficial Escribiente & 300 & $\begin{array}{l}\text { 17-03-1779 } \\
\text { (falleció 03-06-1784) }\end{array}$ \\
\hline Josef Bonifacio Zamudio & Oficial Escribiente & 400 & 21-02-1785 \\
\hline Francisco Paula Marin & Oficial Escribiente & 300 & $12-08-1780$ \\
\hline Fernando Echalecu & Oficial Escribiente & 300 & $20-05-1781$ \\
\hline Manuel Jolga & Oficial Escribiente & 300 & 21-02-1785 \\
\hline Manuel Espinosa & oficial Escribiente & 300 & 01-01-1786 1era creación. \\
\hline Gregorio Canedo & Oficial de tesorería & 500 & $\begin{array}{l}\text { 7-04-1779 (hasta 01-01-1786 } \\
\text { que ascendió a oficial de con- } \\
\text { taduría). }\end{array}$ \\
\hline $\begin{array}{l}\text { Bernardo Gonzales } \\
\text { Bueno }\end{array}$ & $\begin{array}{l}\text { Oficial Escribiente de } \\
\text { Tesorería }\end{array}$ & 400 & $\begin{array}{l}\text { 16-04-1179 (hasta que es } \\
\text { nombrado como oficial de ha- } \\
\text { cienda de Lima el 30-11-1783) }\end{array}$ \\
\hline Luis Zaldarriaga & Oficial cajero & 300 & $\begin{array}{l}\text { 1-04-1779 (hasta que fue } \\
\text { nombrado segundo oficial de } \\
\text { contaduría) }\end{array}$ \\
\hline $\begin{array}{l}\text { Manuel Vicente de la } \\
\text { Colina }\end{array}$ & Ramo de sisa & 800 & $14-04-1780$ \\
\hline Jossep del Pozo & Receptor de alcabalas & 400 & 18-04-1784 \\
\hline Rafael de los Reyes & $\begin{array}{l}\text { Segundo Oficial de recep- } \\
\text { toría de alcabalas }\end{array}$ & 300 & $18-04-1784$ \\
\hline Pedro López Bustamante & $\begin{array}{l}\text { Tercer Oficial de recepto- } \\
\text { ría de alcabalas }\end{array}$ & 300 & $18-04-1784$ \\
\hline
\end{tabular}

Fuente: Cuadro de elaboración propia AGN.X-14-8-3.

53 Linda Salvucci, "Costumbres viejas, hombres nuevos: José de Gálvez y la burocracia fiscal novohispana (1754-1800)” en Historia mexicana, 33, 2, 1983, pp. 224-264. 
Susan Socolow indica que 65\% de los hombres que ocuparon los cargos de la Aduana porteña eran peninsulares, que ya poseían amplia trayectoria en el servicio real en otros espacios de la monarquía. El mismo Ximénez de Mesa de origen malagueño y antes de ocupar la vacancia aduanera era Alcalde Mayor en Tabasco, Nueva España. Entre los años de 1779 y de 1810, los cargos principales fueron ocupados por hombres con tales orígenes y trayectorias. Como, por ejemplo, 4 de los 5 administradores que tuvo la Aduana y 6 de los 7 contadores. Para el puesto de oficial de contaduría, de un total de 14, se computan 7 peninsulares y 7 americanos. ${ }^{54}$ A pesar de la distinción por origen, los magistrados continuaron replicando conductas arraigadas en sus prácticas administrativas como la malversación de fondos reales. Tales conductas posibilitaban crear lazos e intereses con las elites americanas.

Integrar la nómina de personal de la Real Aduana permitía garantizar un sueldo seguro y convertirse en fiel servidor del rey. En su oficio, los servidores, se disponían a la administración directa de la contaduría y tesorería de este despacho y con ello a los fondos del erario real ${ }^{55}$, que anualmente debían ser remitidos a la Real Hacienda. La ejecución de esas acciones permitiría materializar los objetivos de la Corona, es decir la centralización de las rentas aduaneras. A su vez la autonomía en las prácticas disponía a los servidores a que utilizaran su cargo para establecer vínculos económicos con los actores locales entre los que se destacan los comerciantes. Esta situación era tolerada en tanto la aduana cumpliera con su rendición de cuentas al erario real. El abandono de las obligaciones del oficio fue el límite de tolerancia de la Corona. El atraso en la rendición de cuentas trajo aparejada la quiebra del primer administrador, arrastrando consigo a miembros de la elite local por estar involucrados en los negociados realizados con los fondos de la aduana y evidentemente a costa de la Corona. Este hecho desencadenó un extenso juicio que se inició en 1788, tras la intervención directa del Virrey el Marqués de Loreto, que movilizó a las autoridades centrales en ambos lados del Atlántico.

El juicio permite observar que los magistrados y oficiales de la Aduana porteña veían provechoso su ascenso al cargo, puesto que las oportunidades comerciales en la región les permitían incurrir en negociados personales. La posibilidad se convirtió en una realidad. A pesar de ser precisas las instrucciones dadas para el óptimo funcionamientodel despacho, desde su instalación la institución fue sinónimo de desidia y de codicia individual. A

${ }^{54}$ Susan Socolow, The Bureaucrats, p.132.

${ }_{55}$ En el capítulo 5 del Reglamento de Aduanas de 1779 se precisan las tareas de cada servidor. El control externo quedaba a cargo Superintendente de Real Hacienda. El administrador real tenía jurisdicción en los manejos internos de su despacho. AGN, IX -14-8-3. 
María Evangelina Vaccani

continuación presentaremos la quiebra de Francisco Ximénez de Mesa para dilucidar sus negociados y prácticas.

\section{La quiebra}

El 10 de septiembre de 1788 se decretó la quiebra ${ }^{56}$ del Francisco Ximénez de Mesa por haber cometido abusos sobre su oficio como Administrador de la Real Aduana porteña y malversado los fondos del Erario Real. Según José Canga Arguelles quiebra significa:

... en hacienda, lo mismo que en el comercio, representa el estado de falencia de los que manejan los fondos públicos; es decir, cuando de la liquidación de sus cuentas aparece que han recibido mayores sumas que las de que dan legítima salida en ellas. La quiebra puede provenir, o de haber invertido en sus propios usos los caudales de la hacienda el que los tenía a su disposición, o de haber usado de ellos con ánimo de reintegrarlos. ${ }^{57}$

En uno y otro caso, aunque se reintegrasen los faltantes, todo depositario, tesorero o administrador quedaría privado de empleo, e inhabilitado para obtener otro alguno en el servicio real, habida cuenta de que se había incurrido en un delito de lesa majestad.

La acusación fue doble. Por un lado, por ocultamiento de fondos y, por el otro, por la utilización del cargo para el desarrollo de negociados particulares. La quiebra del administrador de la aduana es conocida por sus íntimos y amistosos vínculos comerciales con Domingo Belgrano ${ }^{58}$, quien se vio involucrado en las fraudulentas acciones de Ximénez..$^{59} \mathrm{El}$ extenso juicio puede ser utilizado para comprender el accionar de los servidores al frente de la institución en cuestión.

Ximénez de Mesa se desempeñó como Administrador de la Aduana entre el $1^{\circ}$ de marzo de 1779 y el 10 de septiembre de 1788 , cuando fue apresado por orden del virrey

${ }^{56} \mathrm{El}$ término fue utilizado para analizar el caso de la quiebra de los funcionarios de las Reales Cajas de Oruro y Carangas. Ver: María Concepción Gavira Márquez, "El escándalo de las quiebras en la Real Hacienda Las Cajas Reales de Oruro y Carangas, 1784-1804” en Bolivian Studies Journal, 18, 2011, pp. 161-183.

57 José Canga Arguelles, Diccionario de Hacienda para el uso de los encargados de la suprema dirección de ella, Tomo 5, Londres, Imprenta española de M. Calero, 1827, p. 5.

${ }^{5}$ Jorge Gelman analiza la trayectoria de Belgrano y vincula su crecimiento comercial a la apertura dada por el libre comercio en 1778, sin considerar la liquidez obtenida en el trato preferencial en la Aduana. Jorge Gelman, De mercachifle a gran comerciante: los caminos del ascenso en el Río de la Plata colonial, Sevilla, Universidad Nacional de Andalucía, 1996. ${ }_{59}$ Miguel Bravo Tedín, Belgrano y su sombra, 2011, http://www.lariojacultural.com.ar/imagenesdin/noticias/Archivos/717-46387.pdf (consulta 03/03/2015), María Evangelina Vaccani, "Las quiebras en el Antiguo Régimen: los vínculos entre el Administrador de la Real Aduana porteña Francisco Ximénez de Mesa y el comerciante Domingo Belgrano Pérez (1779-1788)" en XI Jornadas de Investigadores en Historia, Universidad Nacional de Mar del Plata, 16-18 de noviembre del 2016. 
Marqués de Loreto. El virrey había recuperado las atribuciones de control hacendario frente a los conflictos de competencias jurisdiccionales que se habían presentado con el Superintendente Francisco Paula de Sanz. Las acusaciones que recayeron sobre Ximénez de Mesa fueron los fraudes hechos sobre las cajas. ${ }^{60}$ Tras el apresamiento y quiebra una decena de cómplices se ven involucrados y son enjuiciados también. ${ }^{61}$ Entre ellos se destaca el Comandante del Resguardo de Mar y Tierra Francisco de Ortega de Monroy, instalado en la banda norte del río, en el muelle montevideano. También destaca el Cajero de la aduana porteña Luis Zaldarriaga, que fue reconocido como cómplice principal en el ocultamiento y fraude de fondos.

Volver sobre el juicio permite estudiar el accionar de estos individuos en la sociedad rioplatense. Por eso es preciso señalar que desarrollaron negociados que su capacidad política y margen de acción les permitían sostener desde su cargo real. Claro está, que sin llamar la atención de las autoridades.

El proceso judicial se extiende entre 1788 y 1804, mientras se buscó el modo de subsanar los errores derivados de la fraudulenta administración y reparar las faltas cometidas para con el Erario Real. Las actuaciones emprendidas se dieron todas bajo el signo de la ley, poniendo en jaque a las autoridades a un lado y otro del Atlántico. Como primera medida, se procedió al embargo de todos los bienes y papeles personales de los involucrados. Luego, por orden expresa del virrey, se solicitó a todos los escribanos del Virreinato y de aquellos lugares en que los reos llevaron asuntos comerciales que revisasen sus protocolos para encontrar rastros de los negocios en pos de continuar con los procedimientos de embargo. ${ }^{62}$ Los resultados arrojados revelan la intensa actividad mercantil de Belgrano y, sorpresivamente, los escasos bienes que poseía Ximénez de Mesa, que se reducían a una hacienda pobre, productora de cacao en Tabasco (Nueva España) y unos pocos pesos en su haber. ${ }^{63}$

En este punto cabe precisar que los vínculos personales establecidos entre los servidores reales y las elites mercantiles permitían materializar sus intenciones económicas en la estructura de gobierno y de poder de la Corona. En una sociedad de Antiguo Régimen los privilegios y contraprestaciones eran fundamentales para mantener el equilibrio social. Es

\footnotetext{
${ }^{60}$ Archivo General de Indias (en adelante AGI), ES.41091 /23.1//BUENOS_AIRES,510 (1789-1805): Causa sobre desfalco de caudales seguida al Administrador de la Aduana y otros varios empleados. Secretaría de Estado y del Despacho de Hacienda de Indias. Folio $n^{\circ}$ 238-241, Consejo de Indias, 2 de septiembre de 1790.

${ }^{61}$ AGI, ES.41091 /23.1//BUENOS_AIRES,510 (1789-1805). Folio n ${ }^{\circ}$ 237-238, Consejo de Indias, 2 de septiembre de 1790. ${ }^{62}$ AGN, IX- 32-4-7, Leg. ${ }^{\circ}$ 5. Criminales, 1789.

${ }^{63}$ Archivo General de la Nación de México (en adelante AGNM), Reales Cédulas. Vol. 145, n² 2415, Madrid, o9/o7/1791
} 
así, que la Corona prefería perder un poco de margen de acción, tolerando las acciones de sus servidores, al tiempo que garantizaba el cumplimiento de sus objetivos de mínima. Para el caso del Río de la Plata, las máximas autoridades en asuntos fiscales al verse privadas de los ingresos aduaneros destinados a cubrir las urgencias fiscales, dispusieron poner fin a tal situación. Al decretarse la quiebra de Ximénez, se observa que su "armazón” socioeconómica no pudo responder a las urgencias fiscales y las autoridades se dispusieron a restablecer el equilibrio de poderes y reparar el desfalco al erario real. Se nombra administrador provisorio a Juan José Núñez, quien se desempeñaba como Contador y a Ángel Izquierdo para reemplazarlo en su antigua función. ${ }^{64}$

Siguiendo con la quiebra, Ximénez de Mesa y Francisco de Ortega como servidores de la aduana entablaron relaciones estrechas con los comerciantes rioplatenses. Sus vínculos de amistad les permitieron materializar sus intereses particulares en las aduanas y desplegarlos sin injerencia directa de la Corona. De este modo, vemos cómo sus objetivos económicos se concretaron en estrecha vinculación con el cargo y funciones que desempeñaban. Logrando burlar las imposiciones arancelarias de las rentas aduaneras que ellos mismos debían patrocinar, al tiempo que se beneficiaban del régimen mercantil que se dispuso a reglamentar la actividad comercial en los puertos de Buenos Aires y Montevideo $^{65}$. A su vez, entablaron vínculos personales con actores locales con miras a diversificar sus ingresos. Ejemplo de ello es la estrecha relación de amistad y comercial que establece Ximénez con Domingo Belgrano, quien contaba con una extensa red mercantil. La compañía de carretillas de Ximénez en sociedad con Antonio Ruiz, la cual estaba al servicio de la Aduana. ${ }^{66} \mathrm{El}$ negocio de salazón de carnes que fue montado por Ortega junto a su socio el hacendado Francisco Medina ${ }^{67}$. Los envíos de mercancías fuera de registro que existían entre el Administrador y el Comandante del Resguardo a un lado y otro del Río de la Plata, así como también la libertad que se concedían mutuamente de introducir frutos prohibidos. $^{68}$

La tolerancia a tales hechos llegó a su fin cuando el Tribunal de Cuentas toma

\footnotetext{
${ }^{64}$ AGN. IX, Tomas de Razón, Tomo XXXI. Títulos de los empleados de la Real Aduana de Buenos Aires y receptores de la jurisdicción, (1778-1790).

${ }_{55}^{6}$ María Evangelina Vaccani, "El Comandante de Resguardo de Montevideo. Francisco de Ortega y Monroy: servicio real y defensa de honor en la sociedad de Antiguo Régimen" en I Jornadas de Jóvenes Investigadores en Historia, Universidad Nacional de Tres de Febrero, Caseros, 2016.

${ }^{66}$ AGN, XI, Bandos reales, Libro 6, fojas 317 a 323.

${ }^{67}$ AGI, ES.41091 /23.1//BUENOS_AIRES,510 (1789-1805)... Folio n ${ }^{\circ}$ 245-250, Consejo de Indias, 2 de septiembre de 1790.

${ }^{68}$ Se conserva una copiosa correspondencia entre Francisco de Ortega y Francisco Ximénez entre la documentación consultada. Contiene evidencias de los delitos de los que son acusados. AGN, IX -32-4-4, n ${ }^{\circ}$ 6, Leg. 32, Exp. 9, 1788. Las acciones económicas de estos actores se analizan en $\mathrm{M}^{\mathrm{a}}$. E. Vaccani, "El Comandante de Resguardo".
} 
cartas en el asunto, por las advertencias de Manuel Ignacio Fernández, Superintendente de la Real Hacienda, quien desde 1785 reclamaba a Ximénez la liquidación de las cuentas de la contaduría que él administraba. ${ }^{69}$ En este punto es interesante señalar la incapacidad del Tribunal Mayor de Cuentas en lo que respecta al control de las liquidaciones de las tesorerías virreinales frente a la autoridad del Superintendente. José María Mariluz Urquijo al respecto indica la quiebra del administrador “podría haberse evitado si desde los principios se hubiese estado a la mira de su manejo, obligándosele a rendir sus cuentas anualmente sin admitirle las frívolas excusaciones de que se valió para postergar su presentación"70, entre las que figuran en sus declaraciones la de haber utilizado los fondos para cubrir situados a cuenta de su tesorería ${ }^{71}$. Una vez decretada la quiebra el máximo Tribunal de fiscalización se dispuso a revisar el engorroso estado de las finanzas del despacho aduanero indicando al respecto que:

... se expresa que como resultado de esta labor llegó a deducir el alcance líquido de 251.939 pesos. Ximénez de Mesa sólo había prestado fianza por valor de 10.000 pesos, suma que como hacía notar el tribunal, era desproporcionada a la magnitud de los intereses que administraba. ${ }^{72}$

Los excesos puestos al descubierto tras la quiebra de este sujeto y sus cómplices permiten dilucidar las intenciones de los individuos al frente de la Aduana. El acceso a la administración de los despachos aduaneros en una región próspera como lo era la rioplatense les permitía mucho más que ganarse la vida al servicio del rey. La idea de "buen gobierno" suponía una ordenada administración del ramo aduanero. Aprovechando la inoperancia de los controles superiores, atravesados por conflictos de competencia en materia hacendaria y el retraso general de las cuentas ${ }^{73}$, Ximénez se sintió habilitado para dilatar la rendición de los balances de su tesorería y se excusara sin fundamentos sólidos. Tal situación fue tolerada por casi nueve años. A pesar de las acciones de las autoridades tras la quiebra de Ximénez, las medidas emprendidas no bastaron para remediar el desorden y atraso en las cuentas del Erario Real.

\footnotetext{
${ }^{69}$ Las actuaciones del Tribunal: “constan las providencias que en el año ochenta y cinco expidió el tribunal de cuentas para estrechar al administrador Ximénes que rindiese las de su administración a tiempo vencido (...) por el mes septiembre del año ochenta y seis, sólo se consiguió que el administrador Ximénes, presentase las dos primeras cuentas de los años setenta y nueve y ochenta, dificultando la data de las subsecuentes por el rezago que había, (...)”. AGN, IX-239-4, Hacienda, papeles sueltos, (1790-1795), Cuentas exigidas al ex administrador de la Aduana Francisco Ximénez de Mesa, Vista del 30 de septiembre de 1789. .

$7^{\circ}$ J. Ma . Mariluz Urquijo, "El Tribunal Mayor”, p. 155.

${ }^{71}$ AGI, ES.41091 /23.1//BUENOS_AIRES,510 (1789-1805)... Folio n ${ }^{\circ}$ 209, San Lorenzo, 21 de octubre de 1790.

${ }^{72}$ AGN, IX-16- 4-6, Tribunal de Cuentas, costas de julio -diciembre de 1796.

73 Para una comprensión de los conflictos de competencia en relación a las cuentas de la Real Hacienda ver: Ricardo Rees Jones, “Algunas repercusiones jurídicas de la difusión de la Ordenanza de Intendentes de Buenos Aires” en Revista de Historia del Derecho, 15, 1987, pp. 405-432.
} 
Iniciado el siglo XIX y con el propósito de encauzar el desorden en la Real Hacienda producto de la inoperancia del Tribunal de Cuentas se realiza la visita a las cajas virreinales de Diego de la Vega entre el 1802 y 1804. Se procede a la inspección de los despachos de aduanas y como consecuencia es la renovación indicada por César A. Gracia Belsunce, quien analizó el ramo de aduana entre 1805 y 1810 con el fin de precisar sus ingresos. Los años analizados son elegidos por la disponibilidad de documentación y porque considera que en estos años la aduana funcionó bajo una correcta dirección. $\mathrm{Al}$ respecto hace mención que su Administrador, José Proyet, preocupado por el saneamiento de las cuentas e subsanar la inoperancia del personal, reorganiza el sistema contable de la tesorería y contaduría, distinguiendo en los asientos contables los registros de créditos, deudas y de asientos de años anteriores de los del año en curso. ${ }^{74} \mathrm{El}$ hecho permite considerar que la Aduana porteña tras la escandalosa quiebra de su primer administrador continúo siendo una institución en la que la Corona no logró imponer un control, por más que delegase su poder en magistrados peninsulares a los que creía idóneos para tales tareas y fieles a sus propósitos.

\section{Y con los reos: ¿Qué sucedió?}

El destino de estos sujetos es dispar al igual que sus procesos. Francisco Ximénez de Mesa fue recluido en la cárcel real padeciendo extrema miseria. En 1801 regresó a la península y muere inhabilitado para el real servicio y peticionando una pensión.

Domingo Belgrano fue apresado en el calor de su hogar, se determina su quiebra y embargo de bienes, lo que le impide continuar su labor mercantil. Cabe destacar que por Real Cédula en 1791 se ordena que Domingo Belgrano sea apartado de la causa seguida a Ximénez de Mesa. Este hecho impulsa a su esposa, María Josefa González Cesaro, a pedirle a su hijo Manuel que se hallaba en la península que limpie el honor de su padre y de su familia. ${ }^{75}$ Miguel Bravo Tedín, quien trabajó detalladamente el caso de Belgrano, indica que la presencia de Manuel al otro lado del Atlántico fue decisiva para gestionar ante la corte y vínculos cercanos al Rey la absolución de su padre. Cumpliendo con su cometido, lograba limpiar el nombre de su padre en 1795, que fallece al año siguiente con el honor a salvo. ${ }^{76}$

Por su parte, Francisco de Ortega logra escapar del presidio montevideano en 1779, se dirige al Brasil y de allí emprende su regreso a la península, en donde él mismo gestiona

${ }^{74}$ C. A. García Belsunce, "La Aduana de Buenos Aires...”, p. 464.

${ }_{75}$ AGN, IX-32-4-7, Criminales, Leg., 35. Exp., 25, 1791.

${ }^{76}$ M. Bravo Tedín, Belgrano y su sombra, 2011. 
su defensa utilizando sus contactos personales que le permitieron llegar a la corte y peticionar la absolución. Sólo obtuvo medio sueldo para su manutención y se le negó la posibilidad de ocupar alguna vacancia en el servicio real.

\section{Cierre}

El abordaje del caso de la quiebra del primer administrador de la Aduana de Buenos Aires Francisco Ximénez de Mesa, nos permite adentrarnos en la comprensión del sistema de dominación operante en el Río de la Plata. Para ello nos hemos valido de las nuevas interpretaciones que hacen hincapié en la naturaleza del poder como un modelo flexible que caracterizó la Monarquía Hispánica a fines del Siglo XVIII. Complejizando el análisis con el desempeño de los magistrados a partir de sus actuaciones en el Antiguo Régimen y las interpretaciones a partir del tópico de la corrupción.

La investigación en curso busca combinar la dimensión fiscal y su consecuente rama político-institucional, insertando el estudio en la singularidad del Antiguo Régimen en el Río de la Plata. Como hemos presentado, las transformaciones políticas operadas en el siglo XVIII tendieron a la centralización de las rentas en el ramo de aduana. Para el caso de la región rioplatense ello se tradujo en el emplazamiento de las Reales Aduanas de Buenos Aires y de Montevideo, bajo la consolidación del sistema mercantil en el complejo portuario rioplatense con las instrucciones del Reglamento de libre comercio de 1778. Este condensó un proceso de apertura comercial iniciado a principios del siglo XVIII.

En lo que respecta a las instituciones fiscales, se notó la intención de dotarlas de personal especializado, capaz de administrar las crecientes tareas hacendarías. Pero como se vio, acceder a estos puestos en América traía aparejado beneficios económicos, los cuales eran utilizados para enriquecerse a través del manejo de fondos reales y con las consecuentes posibilidades comerciales que desde allí se podían emprender. Ximénez de Mesa como máxima autoridad de la tesorería aduanera supo sortear la rendición de cuentas y hacer de su despacho un trampolín para sus intereses económicos. Estos se hacían en complicidad de sus dependientes y el comerciante de renombre Domingo Belgrano.

Las prácticas fueron toleradas hasta que se sucedieron cambios institucionales que permitieron a las máximas autoridades de la región actuar. El Tribunal de Cuentas porteño insistía en el atraso de los estados de balances de la Aduana. Ante un contexto de cambio de autoridad y la necesidad de fondos en el erario, se dispuso a tomar cartas en el asunto llevando a la quiebra a don Francisco en septiembre de 1788. En mayo de ese 
mismo año el Virrey había recuperado sus atribuciones hacendarías, frente al poder del Superintendente. El proceso judicial iniciado permitió establecer los ilícitos y desplegar acciones políticas a fin de subsanar las faltas cometidas.

El extenso juicio que recayó sobre el administrador y sus asociados posibilita comprender algunas de las acciones económicas que se desarrollaban desde el cargo. Entre ellas hubo negociados mercantiles que en complicidad tenían Ortega y Ximénez a un lado y otro del río, entre los que se destaca el desvío de fondos para emprendimientos económicos y el encubrimiento mutuo de sus actividades mercantiles. Otro ejemplo es la estrecha amistad de Ximénez y Belgrano, que permitió al administrador desarrollar acciones mercantiles bajo el nombre del comerciante y al comerciante obtener beneficios, como retrasar la liquidación de sus deudas con la aduana. También hubo emprendimientos productivos y de servicios que se sostenían en complicidad con terceros.

Vimos que las intenciones de la Corona dependían de la fidelidad de sus funcionarios. Los ilícitos de Ximénez y sus socios fueron tolerados por casi 10 años, ya que se prefería perder ganando. Es decir, tolerar ciertas prácticas en los funcionarios a fin de que la Aduana operase. La inoperancia total del despacho fue el límite a las acciones. La Corona al verse privada de sus recursos fiscales más allá de un límite de tolerancia que no es fácil establecer, buscó por la vía judicial esclarecer las acciones de sus servidores. El extenso juicio no dio una solución definitiva al problema, ya que la Aduana siguió operando en un profundo desorden hasta inicios del siglo XIX.

Finalmente observamos que las "reformas" lograron imprimir una agenda política de la Corona, pero esta dependía de sus interlocutores locales. Los servidores a cargo de la Aduana optaron por cimentar desde sus cargos acciones económicas con la elite local, en vez de responder a la normativa impuesta, tal como se hacía un siglo atrás como lo mostró Z. Moutoukias. De todos modos, la reglamentación aduanera y administrativa es la que dio curso a las acciones económicas de los actores involucrados en la quiebra de Ximénez. Así, las prácticas de los magistrados en pleno intento de absolutizar el poder, replicaron viejas usanzas que se desprendían de la legalidad del sistema operante.

Al mismo tiempo el análisis propuesto pone de manifiesto que el sistema de dominación a fines del siglo XVIII no es reductible a una situación colonial. El impulso centralizador dependió de los cuerpos políticos existentes en la sociedad y el consenso resultante de estos y la Corona. La Aduana de Buenos Aires en manos de magistrados peninsulares 
que en complicidad con la elite local hacían de ellas el canal político para materializar sus intereses económicos, logró poner de manifiesto un imbricado sistema político donde las intenciones y posibilidades de control de la Corona encontraron frenos.

\section{Bibliografía}

Amaral, Samuel, "La Financiación del gasto público en la Hacienda Colonial. Un análisis de las cuentas de la Caja Real de Buenos Aires, 1789-1791”, en Anales de la Asociación Argentina de Economía Política, 17, La Plata, Asociación Argentina de Economía Política, 1982, sin paginación.

Arévalo Hernández, Decsi Astrid; Rodríguez Salazar, Oscar, "La fiscalidad bajo un régimen de dominación colonial: el caso de Caja Real de Cartagena, 1738-1802” en Anuario Colombiano de Historia Social y Cultural, 35, 2008, pp. 19-64.

Assadourian, Carlos Sempat, El sistema de la economía colonial. El mercado interno. Regiones y espacio económico, México, Nueva Imagen, 1983.

Barba, Fernando Enrique, “Algo más sobre el fracaso los derechos diferenciales” en Investigaciones y Ensayos, 55, 2005, pp. 41-49.

Biangardi, Nicolás. "Financiamiento y distribución del gasto en la caja real de Maldonado (Río de la Plata) 1782-1806” en América Latina en la Historia Económica, 23, 2, 2016, pp. 7-35.

Bravo Tedín, Miguel. Belgrano y su sombra, 2011, http://www.lariojacultural.com.ar/imagenesdin/noticias/Archivos/717-46387.pdf (consulta 03/03/2015).

Barriera, Darío, “Un rostro local de la Monarquía Hispánica: justicia y equipamiento político del territorio al sureste de Charcas, Siglos XVI-XVII" en Colonial Latín American Historical Review, 15, 4, 2006, pp. 377-418.

Brading, David, “La España de los borbones y su imperio americano” en Bethel, Leslie (Ed.), Historia de América Latina, Tomo 2, Barcelona, Crítica, 1990, pp. 85-125.

Beltrand, Michel, "Nuevas preguntas, nuevos enfoques. La corrupción en la administración colonial española”, en Andújar Castillo, Francisco; Felices de la Fuente, María del Mar (Coords.), 
Las ventas de cargos y honores en el Antiguo Régimen, Madrid, Biblioteca Nueva, 2011, pp. 46-62.

Brendecke, Arndt; Martín-Romera, María Ángeles, "El «habitus» del oficial real: ideal, percepción y ejercicio del cargo en la monarquía hispánica (siglos XV-XVIII)” en Studia Historica: Historia Moderna, 39, 1, 2017, pp. 23-51.

Canga Argüelles, José, Diccionario de Hacienda para el uso de los encargados de la suprema dirección de ella, Tomo 5, Londres, Imprenta española de M. Calero, 1827.

Capillas de Castellanos, Aurora, Montevideo en el siglo XVIII, Montevideo, Nueva Tierra, 1971.

Cardim, Pedro; Herzog, Tamar; Ruiz Ibáñez, José Javier; Sabatini, Gaetano, Polycentric Monarchies. How did Early Modern Spain and Portugal achieve and maintain global hegemony, Eastbourne, Sussex Academy Press, 2012.

Delgado Ribas, Josep María, "Presión fiscal y asignación de recursos en la Monarquía borbónica” en Illes i Imperis, 8, 2006, pp. 25-40.

Delgado Ribas, Josep María, “Construir el estado, destruir la nación. Las reformas fiscales de los primeros borbones y el colapso del sistema de equilibrios en el imperio español (17141796)”, Illes i Imperis, 12, 2012, pp. 63-85.

Elliott, John H., “A Europe of Composite Monarchies” en Past and Present, 137, 1992, pp. 48-71.

Elliott, John H., Imperios del mundo Atlántico. España y Gran Bretaña en América (1492-1830), Madrid, Taurus, 2006.

Garavaglia, Juan Carlos, "El Río de la Plata en sus relaciones atlánticas: una balanza comercial (1779-1784)" en Garavaglia, Juan Carlos, Economía, sociedad y regiones, Buenos Aires, Ediciones de la Flor, 1987, pp. 65-117.

Gavira Márquez, María Concepción, "El escándalo de las quiebras en la Real Hacienda Las Cajas Reales de Oruro y Carangas, 1784-1804” en Bolivian Studies Journal, 18, 2011, pp. 161-183. 
García Belsunce, César A. "La Aduana de Buenos Aires en las postrimerías del régimen colonial” en Investigaciones y Ensayos, 19, 1975, pp. 463-486.

Gelman, Jorge, De mercanchifle a gran comerciante: los caminos del ascenso en el Río de la Plata colonial, Sevilla, Universidad Nacional de Andalucía, 1996.

Gelman, Jorge, "La lucha por el control del Estado: administración y elites en Hispanoamérica”, en Tándeter, Enrique (Dir.); Hidalgo Lehuedé, Jorge (Co-dir.), Historia General de América Latina. Tomo IV. Procesos americanos hacia la redefinición colonial, España, s/d, Ediciones de la UNESCO/Editorial Trotta, 2000, pp. 251-264.

Andrés Gallego, José, “Los Reinos de Indias, de tierra de conquista a sumisión pactada” en Conrad Russell; José Andrés Gallego (Dirs.), Las monarquías del Antiguo Régimen, ċmonarquías compuestas?, Madrid, Editorial Complutense, 1996, pp. 149-164.

Halperín Donghi, Tulio, Guerra y finanzas en los orígenes del estado argentino (1791-1850). $1^{\mathrm{a}}$ ed. 1982, Buenos Aires, Prometeo Libros, 2005.

Haring, Clarence, El Imperio Hispánico en América, Buenos Aires, Ed. Peuser. 1958.

Hespanha, Antonio, Vísperas de Leviatán. Instituciones y poder político (Portugal, siglo XVII), Madrid, Taurus, 1989.

Ibarra, Antonio; Valle Pavón Guillermina del, "Las aduanas durante el virreinato en la Nueva España” en Florescano, Enrique (Coord.), Historia General de las Aduanas en México, México, Confederación de Asociaciones de Agentes Aduanales, 2004, pp. 53-110.

Imízcoz Beunza, José María, "Comunidad, red social y elites. Un análisis de la vertebración social en el Antiguo Régimen”. En: Imízcoz Beunza, José María (Dir.). Elites, poder y red social. Las élites del País Vasco y Navarra en la Edad Moderna. Bilbao: Universidad del País Vasco, 1996, pp. 13-50.

Irigoin Alejandra; Grafe Regina, "Bargaining for Absolutism. A Spanish Path to Nation State and Empire Building” en Hispanic American Review, 88, 2, 2008, pp. 173-209. 
Jumar, Fernando, "El precio de la fidelidad. La Guerra de Sucesión en el Río de la Plata, los intereses locales y el campo Borbón” en Molinié, Annie y Merle Alexandra, (Dirs.). L'Espagne et ses guerres. De la fin de la Reconquête aux guerres de l'Indépendance, París, Presses de l’Université Paris - Sorbonne, 2004, pp. 203-236.

Jumar, Fernando, Le commerce atlantique au Río de la Plata, 1680-1778, 2da. ed. aumentada, $1^{\mathrm{a}}$ ed. electrónica, La Plata, UNLP, 2010, http://www.memoria.fahce.unlp.edu.ar/tesis/ te.364/te.364.pdf.

Jumar, Fernando, "La región Río de la Plata y su complejo portuario durante el Antiguo Régimen”, en: Raúl Fradkin (Dir.), Historia de la provincia de Buenos Aires. Tomo 2. De la conquista a la crisis de 1820, Buenos Aires, Edhasa, 2012, pp. 124-157.

Jumar, Fernando; Sandrín, María Emilia, "La estructura del gasto de la Real Hacienda en Buenos Aires, 1734-1742. La Corona y la economía local” en Sánchez Santiró, Ernest (Coord.), El Gasto Público en los imperios ibéricos, S. XVIII, México, Instituto Mora, 2015, pp. 205-272.

Klein, Herbert, “Las finanzas del Virreinato del Río de la Plata en 1790” en Desarrollo Económico, $13,50,1973$, pp. 369-400.

Kraselsky, Javier, "Las estrategias de los actores del Río de la Plata: las Juntas y el Consulado de comercio de Buenos Aires a fines del Antiguo Régimen (1748-1809)”, Tesis de Doctorado inédita, Universidad Nacional de La Plata, 2011.

Laviana Cuetos, María Luisa "Comercio y fisco: los «productos de la Aduana» de Guayaquil (17571804)" en Europa e Iberoamérica, cinco siglos de intercambios, V. II, Sevilla, Junta de Andalucía, 1992, pp. 599-615.

Lynch, John, Administración colonial española 1782-181o. El sistema de Intendencias en el Virreinato del Río de la Plata, Buenos Aires, EUDEBA, 1962.

Lynch, John, La España del siglo XVIII, Barcelona, Crítica, 2005.

Levene, Ricardo, Investigaciones acerca de la historia económica del virreinato del Plata. $1^{\mathrm{a}}$ ed. 1927-1928. Segunda edición corregida y ampliada, 2 vols., Buenos Aires, El Ateneo, 1952. 
Mariluz Urquijo, José María, "El Tribunal Mayor y Audiencia Real de Cuentas de Buenos Aires” en Revista española de control externo, 2, 4, 1951, pp. 129-158.

Morelli, Federica, Territorio o Nación. Reforma y disolución del espacio imperial en Ecuador, 1765-1830. Madrid: Centro Político y Constitucional, 2005.

Moutoukias, Zacarías, Contrabando y control colonial en el siglo XVII, Buenos Aire, CEAL, 1988.

Moutoukias, Zacarías, "Burocracia, contrabando y autotransformación de las elites en el siglo XVII" en Anuario IEHS, 3,1998, pp. 213-248.

Pietschmann, Horst, “Burocracia y corrupción en Hispanoamérica colonial. Una aproximación tentativa” en Nova América, 5, 1985, pp. 11-37.

Perusset, Macarena, “Conductas y procedimientos fuera de la ley: comercio ilícito, líderes y prácticas”, Universitas humanística, 63, 2007, pp. 203-239.

Levene, Ricardo, “El Virreinato del Río de la Plata (1776-1810)”, en Ricardo Levene (Dir. Gral.), Historia de la Nación Argentina (Desde los orígenes hasta la organización definitiva en 1862), Tomo IV, $1^{\text {a }}$ sección, Buenos Aires, El Ateneo, 1940, pp. 33-305.

Rees Jones, Ricardo, “Algunas repercusiones jurídicas de la difusión de la Ordenanza de Intendentes de Buenos Aires” en Revista de Historia del Derecho, 15, 1987, pp. 405-432.

Romano, Ruggiero, Coyunturas opuestas: la crisis del siglo XVII en Europa e Hispanoamérica, México, El Colegio de México/Fondo de Cultura Económica, 1993.

Saguier, Eduardo, "La corrupción de la burocracia colonial borbónica y los orígenes del federalismo: el caso del Virreinato del Río de la Plata” en Anuario de Historia de América Latina, 29, 1992, pp. 149-178.

Salvucci, Linda, "Costumbres viejas, hombres nuevos: José de Gálvez y la burocracia fiscal novohispana (1754-1800)" en Historia mexicana, 33, 2, 1983, pp. 224-264.

Socolow, Susan, The Bureaucrats of Buenos Aires, 1769-1810: Amor al Real Servicio, Durham, Duke University Press, 1987. 
Ruiz Torres, Pedro, Reformismo e Ilustración, Historia de España, V, Barcelona, Crítica, Marcial Pons, 2008.

Torres Sánchez, Rafael, La llave de todos los Tesoros. La Tesorería General de Carlos III, Madrid, Silex, 2012.

Torres Sánchez, Rafael, El precio de la Guerra. El Estado fiscal-militar de Carlos III (1779-1783), Madrid, Marcial Pons, 2013.

Vaccani, María Evangelina, "Las quiebras en el Antiguo Régimen: los vínculos entre el Administrador de la Real Aduana porteña Francisco Ximénez de Mesa y el comerciante Domingo Belgrano Pérez (1779-1788)” en XI Jornadas de Investigadores en Historia, Universidad Nacional de Mar del Plata, 16-18 de noviembre del 2016.

Vaccani, María Evangelina, "El Comandante de Resguardo de Montevideo. Francisco de Ortega y Monroy: servicio real y defensa de honor en la sociedad de Antiguo Régimen" en I Jornadas de Jóvenes Investigadores en Historia, Universidad Nacional de Tres de Febrero, Caseros, 2016.

Vaccani, María Evangelina, "Habilitan puerto, se lanza el libre comercio. La creación de las reales Aduanas en el Virreinato del Río de la Plata: antecedentes y realidad mercantil. (17741794)" en 5tas Jornadas Interdisciplinarias de Estudios Portuarios, Red Interdisciplinaria de Estudios Portuarios, 2013.

Vaccani, María Evangelina, “Antecedentes para la conformación de la estructura fiscal: el caso del Virreinato del Río de la Plata y la Real Aduana de Buenos Aires (1700-1810 en IV Jornadas de Graduados-Jóvenes investigadores, Facultad de Humanidades y Ciencias de la Educación, Universidad Nacional de La Plata, 2012.

Wasserman, Martín (Coord.), "Gobierno y Administración de los Erarios de la Monarquía Hispana en las Indias, siglo XVIII" en Anuario del Instituto de Historia Argentina, Universidad Nacional de La Plata, 18, 2, 2018.

Weber, Max, Economía y sociedad. Esbozo de sociología comprensiva, Trad. de José Medina Echavarría y otros, ed. preparada por Johannes Winckelmann, notas José Medina Echavarría, $2^{\mathrm{a}}$ ed., $17^{\mathrm{a}}$ reimpresión, México, Fondo de Cultura Económica, 2008. 